\title{
Distribution and Composition of Thiotrophic Mats in the Hypoxic Zone of the Black Sea (150-170 m Water Depth, Crimea Margin)
}

\author{
Gerdhard L. Jessen ${ }^{1 *}$, Anna Lichtschlag ${ }^{1 \dagger}$, Ulrich Struck ${ }^{2}$ and Antje Boetius ${ }^{1,3}$ \\ ${ }^{1}$ HGF-MPG Group for Deep Sea Ecology and Technology, Max Planck Institute for Marine Microbiology, Bremen, Germany, \\ ${ }^{2}$ Museum für Naturkunde, Leibniz-Institut für Evolutions- und Biodiversitätsforschung, Berlin, Germany, ${ }^{3}$ Alfred Wegener \\ Institute, Helmholtz Center for Polar and Marine Research, Bremerhaven, Germany
}

\section{OPEN ACCESS}

Edited by:

Mark Alexander Lever,

ETHZürich, Switzerland

Reviewed by:

Brandi Kiel Reese,

Texas A\&M University-Corpus Christi,

USA

Julie L. Meyer,

University of Florida, USA

*Correspondence:

Gerdhard L. Jessen gjessen@mpi-bremen.de

${ }^{\dagger}$ Present address: Anna Lichtschlag,

National Oceanography Center, University of Southampton Waterfront

Campus, Southampton, UK

Specialty section: This article was submitted to Extreme Microbiology, a section of the journal Frontiers in Microbiology

Received: 30 March 2016 Accepted: 14 June 2016

Published: 29 June 2016

Citation:

Jessen GL, Lichtschlag A, Struck U and Boetius A (2016) Distribution and Composition of Thiotrophic Mats in the Hypoxic Zone of the Black Sea

(150-170 m Water Depth, Crimea

Margin). Front. Microbiol. 7:1011. doi: 10.3389/fmicb.2016.01011
At the Black Sea chemocline, oxygen- and sulfide-rich waters meet and form a niche for thiotrophic pelagic bacteria. Here we investigated an area of the Northwestern Black Sea off Crimea close to the shelf break, where the chemocline reaches the seafloor at around 150-170 m water depth, to assess whether thiotrophic bacteria are favored in this zone. Seafloor video transects were carried out with the submersible JAGO covering $20 \mathrm{~km}^{2}$ on the region between 110 and $200 \mathrm{~m}$ depth. Around the chemocline we observed irregular seafloor depressions, covered with whitish mats of large filamentous bacteria. These comprised $25-55 \%$ of the seafloor, forming a belt of $3 \mathrm{~km}$ width around the chemocline. Cores from the mats obtained with JAGO showed higher accumulations of organic matter under the mats compared to mat-free sediments. The mat-forming bacteria were related to Beggiatoa-like large filamentous sulfur bacteria based on $16 S$ rRNA sequences from the mat, and visual characteristics. The microbial community under the mats was significantly different from the surrounding sediments and enriched with taxa affiliated with polymer degrading, fermenting and sulfate reducing microorganisms. Under the mats, higher organic matter accumulation, as well as higher remineralization and radiotracer-based sulfate reduction rates were measured compared to outside the mat. Mat-covered and mat-free sediments showed similar degradability of the bulk organic matter pool, suggesting that the higher sulfide fluxes and subsequent development of the thiotrophic mats in the patches are consequences of the accumulation of organic matter rather than its qualitative composition. Our observations suggest that the key factors for the distribution of thiotrophic mat-forming communities near to the Crimean shelf break are hypoxic conditions that (i) repress grazers, (ii) enhance the accumulation and degradation of labile organic matter by sulfate-reducers, and (iii) favor thiotrophic filamentous bacteria which are adapted to exploit steep gradients in oxygen and sulfide availability; in addition to a specific seafloor topography which may relate to internal waves at the shelf break.

Keywords: microbial mats, hypoxia, labile organic matter accumulation, bacterial and archaeal communities, sulfide oxidation, sulfate reduction 


\section{INTRODUCTION}

Thiotrophic microbial mats are dense, visible accumulations of microorganisms, dominated by functional groups capable to gain their energy by using reduced forms of sulfur as electron donors, enabling chemoautotrophic biomass production. They are found at the oxic-anoxic interface of sediments and rocks characterized by high fluxes of sulfide (Macalady et al., 2008; Jørgensen, 2010 and references therein). Typical marine matforming thiotrophs inhabiting shelf sediments are "Candidatus Maribeggiatoa spp." (Teske and Nelson, 2006; nomenclature from Salman et al., 2011), "Ca. Marithioploca spp." (Gallardo, 1977; nomenclature from Salman et al., 2011); Thiomargarita spp. (Schulz, 2006; nomenclature from Salman et al., 2011); "Ca. Marithrix spp."; Thiobacterium spp. (Grünke et al., 2011; nomenclature from Salman et al., 2011) and representatives of the family Thiovulgaceae (Campbell et al., 2006), as well as some types of Arcobacter (Wirsen et al., 2002).

Thiotrophic mats can cover large areas of seafloor in shelf seas and upper continental margins where oxygen depletion leads to high deposition rates of organic matter, such as coastal upwelling regions, oxygen minimum zones and other ecosystems subjected to eutrophication (Jørgensen, 1977; Williams and Reimers, 1983; Schulz and Jørgensen, 2001; Levin, 2003; Mußmann et al., 2003). In these systems, the rapid depletion of oxygen by organic matter remineralization at the seafloor favors high rates of sulfate reduction, and hence sulfide production, which in turn supports the growth of thiotrophs into dense accumulations (Neira and Rackemann, 1996; Freitag et al., 2003; Lehto et al., 2014). Thiotrophic mats are also prominent features of cold seep ecosystems (Grünke et al., 2012), where the anaerobic oxidation of hydrocarbons via sulfate reduction fuels high sulfide fluxes (Boetius et al., 2000; Joye et al., 2004), at sulfide-emitting hydrothermal vents (Jannasch et al., 1989; Meyer et al., 2013; Urich et al., 2014), as well as in caves, profiting from sulfide-rich streams (Macalady et al., 2006).

Among the factors controlling the distribution and thickness of mats in shelf sediments are the fluxes of hydrogen sulfide from the seafloor, and of the electron acceptors oxygen or nitrate from the overlying bottom water (Møller et al., 1985; Schulz et al., 1999; Mußmann et al., 2003; Kamp et al., 2006; Preisler et al., 2007; Grünke et al., 2011). Many of the large sulfur bacteria are able to concentrate and store nitrate in their vacuoles, which they can use as alternative electron acceptor to oxygen, and which helps them to endure fluctuating hypoxic-anoxic conditions (Fossing et al., 1995, Schulz and Jørgensen, 2001; Jørgensen, 2010; Grünke et al., 2011).

The aim of this study was to test if such favorable conditions for the development of thiotrophic mats are met in the Black Sea, especially in its hypoxic zone, where the surface seafloor is in contact with the Black Sea chemocline. Here, the permanent stratification of the water column by a gradient in salinity separates the fresher, oxic surface layer from the permanently anoxic and sulfidic deep water mass (Ross et al., 1970; Murray et al., 2007). At the interface, a chemocline forms, were oxygen and sulfide may co-exist in dynamic equilibrium (Sorokin, 1972; Karl, 1978; Jørgensen et al., 1991). In the water column, the chemocline favors the growth of thiotrophic pelagic bacteria, such as Gammaproteobacteria of the SUP05 cluster (Glaubitz et al., 2013). The Black Sea chemocline persists at about $100 \mathrm{~m}$ in open waters, and deepens towards the margin to depths of 150-160 m (Stanev et al., 2014). Where it meets the seafloor, it exposes the organic rich sediments to variable hypoxic to anoxic conditions (Friedrich et al., 2014). Just below the chemocline, sulfate reduction becomes the dominant remineralization pathway (Jørgensen et al., 2001) increasing from 50 up to $100 \%$ of the total mineralization of organic matter (Weber et al., 2001). This suggests that thiotrophic bacteria could be favored at the interface between the chemocline and the seafloor of the Black Sea outer shelf, as their water column counterpart (Vetriani et al., 2003; Glaubitz et al., 2013). However, previous to this study, the presence and distribution of thiotrophic mats had not been investigated in the Black Sea. Moreover, considering that the development of thiotrophic is one of the most evident response of the microbial community to eutrophication and hypoxia, a better understanding of its distribution and function may enable better predictions of how microbial communities may change with the projected spread of hypoxia and dead zones in the Black Sea and worldwide.

Here we studied the outer Western Crimean shelf by combining submersible surveys with high-resolution geochemical and microbiological analyses, to test the hypothesis that thiotrophic mats could form at the chemocline in hypoxic areas of the Black Sea margin. Key questions addressed were: (i) what are the dominant factors that govern the development of microbial mats? (ii) which microbial types may form mats in the Black Sea, and (iii) what are be the community structure and activity of the mats?

\section{MATERIALS AND METHODS}

\section{Study Area and Seafloor Sampling}

The Black Sea is a semi-enclosed inland sea, and it is the largest natural anoxic water body in the world. The continental shelf reaches about $40 \mathrm{~km}$ from the coast to the shelf break at 100$150 \mathrm{~m}$ depth and the Northwestern Shelf (western Crimea) covers more than $90 \%$ of the total area of the Black Sea shelf (Panin and Jipa, 2002). This zone also receives most of the massive fluvial discharge, which appears as the main driver of eutrophication and hypoxia on the Northwestern Shelf (Capet et al., 2013).

The study area $\left(44.57-44.70^{\circ} \mathrm{N}\right.$ and $32.80-33.15^{\circ} \mathrm{E}, 110-$ $200 \mathrm{~m}$ depth) was located on the Crimean shelf break of the Northwestern Black Sea. Sampling was performed during the MSM 15-1 expedition (R/V Maria S. Merian, 12th April8th May 2010; Figure 1A). In order to assess presence and distribution of microbial mats, 10 video transects were carried out with the submersible JAGO (20 h of video footage, $\sim 2 \mathrm{~h}$ per dive), covering the region between 110 and $200 \mathrm{~m}$ depth, and an area of $20 \mathrm{~km}^{2}$ (Figure 1A). Mats were identified visually by their whitish color, and their dimensions were measured by the laser pointers of JAGO. We observed that the mats were associated with dark patches of particles accumulating 
A

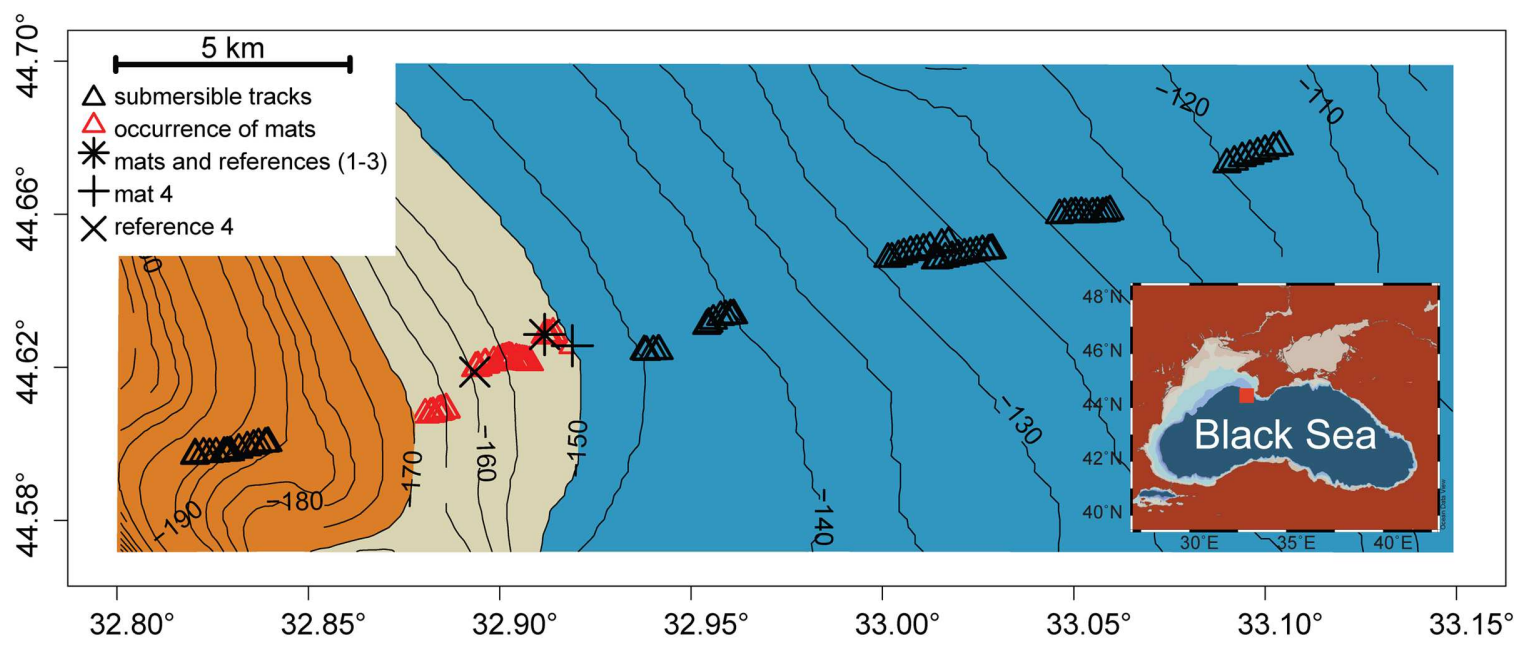

B

C

D

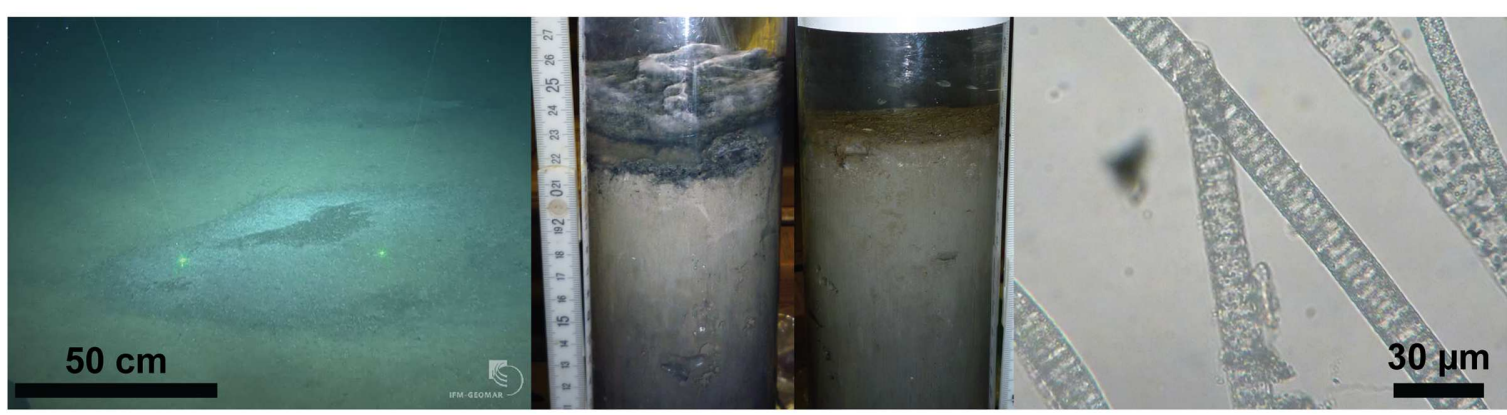

FIGURE 1 | (A) Study area depicting the chemocline (beige belt between 150 and $170 \mathrm{~m}$ depth) between the oxic (blue) and anoxic/euxinic conditions (orange) on the Crimea outer shelf. Submersible dive tracks are represented by black triangles, and the occurrence of microbial mats by the red triangles (see Supplementary Figure S2 for further for details about mat size and distribution). (B) JAGO-based image of accumulated organic matter covered by microbial mats (copyright IFM-GEOMAR), the distance between the two laser pointers is $50 \mathrm{~cm}$. (C) Push cores from mat-covered sediments (left) and reference site (right). (D) Light microscopy image of the mat-forming filamentous bacteria, showing sulfur inclusions.

in seafloor depressions associated with the shelf break. Mats and underlying sediments, as well as mat free sediments were retrieved either by push coring (PUC, inner diameter of $72 \mathrm{~mm}$ ) with the manipulator of the submersible JAGO or with a video-controlled multiple corer (TV-MUC, inner diameter of $96 \mathrm{~mm}$ ). Cores were collected from four different microbial mats, and from three reference sites a few meters away from the mats, on mat-free seafloor outside of depressions (Table 1). An additional sediment core was taken as reference for porewater geochemistry (station ref 4). All sediments were sampled on 4th May 2010 with PUCs except "mat 4" and "ref 4", sampled with a TV-MUC on 26th and 27th April 2010, respectively.

Sampling points and respective labels are summarized in Table 1 and Figure 1A comprehensive characterization of the pore water geochemistry and sediment properties beyond the summary in Table $\mathbf{1}$ can be found at the Earth System database www.PANGAEA.de. ${ }^{1}$

${ }^{1}$ http://doi.pangaea.de/10.1594/PANGAEA.858227

\section{Sensor Measurements}

To assess oxygen concentrations, temperature and salinity in the bottom waters, a CTD-cast profile (SBE 911plus system, with additional sensors for oxygen-SBE43) was taken before TVMUC sampling. In case of the JAGO dives, bottom water oxygen concentration was continuously recorded by an oxygen optode (4330 Mk2 AANDERAA optode, detection limit $1 \mu \mathrm{mol} \mathrm{L}^{-1}$ ) fixed to the frame of the submersible. The optode was calibrated with water samples in which the oxygen concentration was determined by Winkler titration (Winkler, 1888).

High-resolution geochemical gradients of $\mathrm{H}_{2} \mathrm{~S}$ and $\mathrm{pH}$ were measured ex situ with microsensors (Jeroschewski et al., 1996; de Beer et al., 1997) in undisturbed mat-covered sediments (station mat 1 ), and in sediments without mat within $24 \mathrm{~h}$ after collection. Sediments were kept at in situ temperature and were capped until the measurements (to avoid oxygen intrusion). The $\mathrm{H}_{2} \mathrm{~S}$ sensors were calibrated by stepwise increasing $\mathrm{H}_{2} \mathrm{~S}$ concentrations by adding aliquots of a $0.1 \mathrm{~mol} \mathrm{~L}^{-1} \mathrm{Na}_{2} \mathrm{~S}$ solution to acidified seawater $(\mathrm{pH}<2)$. $\mathrm{pH}$ sensors were calibrated with commercial 
TABLE 1 | Biogeochemical composition of mat-covered sediments (mat) and mat-free reference sites.

\begin{tabular}{|c|c|c|c|c|c|c|c|c|}
\hline Sampling site ID & Location (Lat/Long) & Depth (m) & $\mathbf{C}_{\text {org }}(\% \mathrm{dw})$ & TN (\%dw) & $\delta^{13} \mathrm{C}$ & $\mathrm{C}_{\text {org }}: \mathrm{N}$ & Chl a: CPE & DI \\
\hline \multirow[t]{2}{*}{ mat 1} & $44.62696667^{\circ} \mathrm{N}$ & 152 & $4.4 \pm 0.5$ & $0.6 \pm 0.2$ & -24.6 & $8.3 \pm 0.9$ & 0.4 & 1.2 \\
\hline & $32.91266333^{\circ} \mathrm{E}$ & & & & & & & \\
\hline \multirow[t]{2}{*}{ mat 2} & $44.62710167^{\circ} \mathrm{N}$ & 152 & $2.9 \pm 0.8$ & $0.3 \pm 0.2$ & -24.4 & $9.4 \pm 1.3$ & 0.4 & 1.5 \\
\hline & $32.912615^{\circ} \mathrm{E}$ & & & & & & & \\
\hline \multirow[t]{2}{*}{ mat 3} & $44.62740167^{\circ} \mathrm{N}$ & 152 & $4.1 \pm .0 .0$ & $0.5 \pm 0.0$ & -24.6 & $8.7 \pm 0.2$ & 0.4 & - \\
\hline & $32.91257167^{\circ} \mathrm{E}$ & & & & & & & \\
\hline \multirow[t]{2}{*}{ mat 4} & $44.62583333^{\circ} \mathrm{N}$ & 156 & $5.9 \pm 0.9$ & $0.6 \pm 0.3$ & -24.2 & $9.6 \pm 0.2$ & 0.5 & 1.2 \\
\hline & $32.91633333^{\circ} \mathrm{E}$ & & & & & & & \\
\hline \multirow[t]{2}{*}{ ref 1} & $44.62696667^{\circ} \mathrm{N}$ & 152 & $5.0 \pm 0.1$ & $0.6 \pm 0.0$ & -24.2 & $9.9 \pm 0.4$ & 0.4 & 1.6 \\
\hline & $32.91266667^{\circ} \mathrm{E}$ & & & & & & & \\
\hline \multirow[t]{2}{*}{ ref 2} & $44.62711667^{\circ} \mathrm{N}$ & 152 & $1.7 \pm 0.4$ & $0.2 \pm 0.0$ & - & $8.0 \pm 0.4$ & 0.3 & 1.1 \\
\hline & $32.912615^{\circ} \mathrm{E}$ & & & & & & & \\
\hline \multirow[t]{2}{*}{ ref 3} & $44.62718167^{\circ} \mathrm{N}$ & 152 & $3.8 \pm 0.2$ & $0.3 \pm 0.0$ & -24.7 & $8.8 \pm 0.6$ & 0.5 & 1.3 \\
\hline & $32.912615^{\circ} \mathrm{E}$ & & & & & & & \\
\hline
\end{tabular}

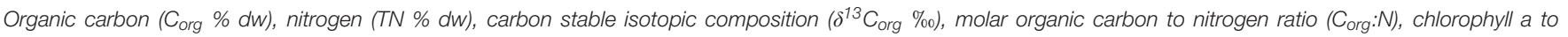

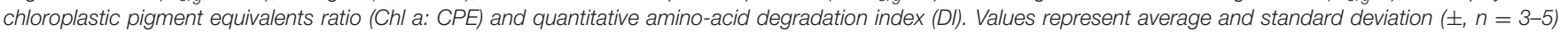
when available, -: no data.

laboratory buffers. The total sulfide $\left(\mathrm{H}_{2} \mathrm{~S}+\mathrm{HS}^{-}+\mathrm{S}^{2-}\right)$ was calculated from the $\mathrm{H}_{2} \mathrm{~S}$ concentrations and the local $\mathrm{pH}$ using equilibrium constants. The sensors were mounted on a motordriven micromanipulator and lowered into the water column and the sediment in increments of $100 \mu \mathrm{m}$. The data acquisition was performed using a DAQ-PAD 6015 (National Instruments Corporation, Austin, TX, USA) and a computer and the flux calculations were performed according to Lichtschlag et al. (2010).

\section{Pore Water Geochemistry}

Pore water from a mat-covered sediment and a reference site was extracted with Rhizons in one $\mathrm{cm}$ intervals (Rhizosphere Research Products, pore size $<0.2 \mu \mathrm{m}$ ) according to SeebergElverfeldt et al. (2005) (station mat 4 and ref 4; Figure 1A). The initial $0.5 \mathrm{~mL}$ was discarded and less than $4 \mathrm{~mL}$ were extracted per Rhizon to prevent mixing between horizons. The retrieved pore water was immediately sub-sampled and fixed in $20 \% \mathrm{Zn}$ acetate (total $\mathrm{H}_{2} \mathrm{~S}$ ), or frozen at $-20^{\circ} \mathrm{C}\left(\mathrm{NH}_{4}^{+}\right.$and $\mathrm{PO}_{4}^{3-}$ ) for further analysis. $\mathrm{NH}_{4}^{+}, \mathrm{PO}_{4}^{3-}$ and total $\mathrm{H}_{2} \mathrm{~S}$ were measured spectrophotometrically using the method of Grasshoff et al. (1983) for nutrients and Cline (1969) to assess total $\mathrm{H}_{2} \mathrm{~S}$ (methylene blue).

In absence of oxygen, sulfate reduction is the most dominant carbon mineralization pathway on the hypoxic-anoxic Crimean shelf break area (Lichtschlag et al., 2015). Thus carbon mineralization was assessed via sulfate reduction and calculated based on stoichiometry according to Thamdrup and Canfield (1996) as follows:

$$
2 \mathrm{CH}_{2} \mathrm{O}+\mathrm{SO}_{4}^{2-} \rightarrow 2 \mathrm{HCO}_{3}^{-}+\mathrm{H}_{2} \mathrm{~S}
$$

\section{Bulk-Sediment Analyses}

Immediately after retrieval, sediments were sliced into $1-\mathrm{cm}$ thick subsamples in a cold room set to in situ temperature $\left(8^{\circ} \mathrm{C}\right)$, and processed for further analyses.
To asses organic matter composition and degradability, samples for organic carbon $\left(\mathrm{C}_{\text {org }}\right)$ and total nitrogen, pigments (chlorophyll $a$ and its degradation products; summed up as chloroplastic pigment equivalents, $\mathrm{CPE}$ ) and total hydrolyzable amino acids (THAA) were measured in triplicate from freeze dried and homogenized sediment.

Pigments (chlorophyll $a$ and CPE) were measured spectrophotometrically according to Schubert et al. (2005). THAA were measured after Pantoja and Lee (2003) from ca. $100 \mathrm{mg}$ sediment. Briefly, after hydrolysis $\left(6 \mathrm{~N} \mathrm{HCl}\right.$ at $105^{\circ} \mathrm{C}$, for $21 \mathrm{~h}$ under $\mathrm{N}_{2}$ gas), the supernatant was removed and neutralized $(0.1 \mathrm{~N} \mathrm{KOH})$. The amino acid identification and quantification was conducted by high performance liquid chromatography (HPLC) after pre-column derivatization with o-phthaldialdehyde and 2-mercaptoethanol (Lindroth and Mopper, 1979; Pantoja and Lee, 1999). The results obtained were used to assess the degradation index (DI) of the organic matter, which represents the selective diagenetic alteration of the sedimentary amino acids as a proxy of lability of the organic matter (Dauwe and Middelburg, 1998; Dauwe et al., 1999). Porosity was determined as the loss of water content of a known volume of sediment before and after drying at $60^{\circ} \mathrm{C}$ until constant weight.

Stable isotope analysis of organic carbon and concentration measurements of nitrogen and carbon were performed simultaneously with a THERMO Delta $\mathrm{V}$ isotope ratio mass spectrometer, coupled to a THERMO Flash EA 1112 elemental analyzer via a THERMO Conflo IV-interface. Before analysis, inorganic carbon was removed by acidification $(12.5 \% \mathrm{HCl}$ solution). Stable isotope ratios are expressed in per mill (\%), the conventional delta notation $\left(\delta^{13} \mathrm{C}\right)$ relative to VPDB (Vienna PeeDee Belemnite standard). Standard deviation for repeated stable isotope measurements of lab standard material (peptone) is generally better than $0.15(\% 0)$ for carbon. Standard deviations of concentration measurements of replicates of our lab standard are $<3 \%$ of the concentration analyzed. 


\section{Sulfate Reduction Rates}

Rates of sulfate reduction (SR) were measured by the whole core injection method (Jørgensen, 1978; Kallmeyer et al., 2004) at stations mat 4 and ref 4 . Here sediments were vertically sub-sampled with subcore liners (250 $\mathrm{mm}$ inner diameter) in triplicate and injected with ${ }^{35} \mathrm{SO}_{4}^{2-}$ radiotracer. After $12 \mathrm{~h}$ incubation in the dark at in situ temperature, the reactions were stopped by transferring the core slices $(1 \mathrm{~cm})$ into $20 \% \mathrm{Zn}$ acetate.

\section{Microbial Community Characterization}

Bacterial filaments and the accompanying communities were assessed by direct light microscopy and the length and width of the filaments were measured using a calibrated ocular micrometer. The total number of cells in the underlying sediments, and in sediments next to mats were assessed in the home laboratory by the Acridine Orange Direct Count (AODC) method. Subsampled sediments were fixed in $2 \%$ formaldehyde/filtered artificial seawater, stored at $4^{\circ} \mathrm{C}$ and treated according to Velji and Albright (1986) and Boetius and Lochte (1996). Single cell numbers were determined by randomly counting at least 30 grids per filter (for two replicate $0.02 \mu \mathrm{m}$ pore size filters).

Total DNA was extracted from ca. $1 \mathrm{~g}$ samples of wet sediment from core sections under the thiotrophic mat, or from sediments next to it, and stored at $-20^{\circ} \mathrm{C}$ using UltraClean Soil DNA Isolation Kits (MoBio Laboratories Inc., Carlsbad, CA, USA). Extracted DNA was quantified with a microplate spectrometer (Infinite ${ }^{\circledR} 200$ PRO NanoQuant, TECAN Ltd, Switzerland) and its concentration adjusted for each step of the subsequent molecular protocol. The bacterial community structure was determined by the automated ribosomal intergenic spacer analysis (ARISA) fingerprinting method according to Fisher and Triplett (1999). Triplicate PCR reactions from standardized amounts of DNA (10 ng) from each sample were amplified using the bacteria forward FAM-labeled primer (ITSF: 5'-GTCGTAACAAGGTAGCCGTA$\left.3^{\prime}\right)$ and reverse primer (ITSReub: 5'-CCAAGGCATCCACC$3^{\prime}$ ) (Cardinale et al., 2004). Fluorescently labeled fragments were determined on a capillary sequencer, and only ARISA fragments in the size range of 100-1000 base pairs (bp) were binned into operational taxonomic units (OTUs) using custom R scripts ${ }^{2}$ (v. 3.0.1) available at http://www.mpibremen.de/en/Software_4.html.

Extracted DNA was amplified and sequenced by the Research and Testing Laboratory (Lubbock Texas, USA) via 454 Massively Parallel Tag Sequencing (454-MPTS). The V4V6 region of the $16 \mathrm{~S}$ rRNA genes were amplified using the bacterial primers 530F (5'-GTGCCAGCMGCCGCGG-3') and 1100R (5'-GGGTTGCGCTCGTTG-3'), and the archaeal primers 349F ( $5^{\prime}$-GYGCASCAGKCGMGAAW-3') and 1048R (5'-CGRCRGCCATGYACCWC-3') according to Klindworth et al. (2013). Fragments were sequenced following the 454MPTS protocol (Margulies et al., 2005) and Titanium reagent chemistry. The raw sequences were processed with mothur (v. 1.29) following a rigorous quality control procedure including

${ }^{2}$ http://www.R-project.org denoising of the flowgrams using an algorithm based on PyroNoise (Quince et al., 2009) removal of PCR errors and a chimera check using UCHIME (Edgar et al., 2011) and average neighbor clustering algorithm (Schloss et al., 2009, 2011, see Supplementary Material for workflow details). Taxonomic assignments were carried out using the SILVA reference file (Pruesse et al., 2007; downloaded from http://www.mothur.org in September 2013) and clustered at a 97\% identity level into operational taxonomic units $\left(\mathrm{OTU}_{0.03}\right)$, and microbial function was inferred from cultured representatives of the identified sequences. The dataset was normalized by the total amount of sequences per sample to get relative abundances, and singletons were removed. 16S rRNA gene sequences of filamentous bacteria are known to be underrepresented in full sediment DNA extracts during PCR, due to epibiont contamination (e.g., Schulz, 2006), and the abundance of sediment-associated microbes (Girnth et al., 2011). Sequences obtained in this study were deposited at EMBL under the project accession number PRJEB11179.

\section{Statistical Analysis}

All statistical analyses were conducted following Ramette (2007 and references therein) using the $\mathrm{R}$ package vegan (Oksanen et al., 2010) and custom R scripts available at http://www.mpibremen.de/en/Software_4.html. The difference in organic matter availability between mat and reference site was assessed by a Student's $t$-test, while the Jaccard dissimilarity index was used to calculate the number of shared OTUs between samples. The bacterial community structure was visualized by applying Nonmetric Multi Dimensional Scaling (NMDS) analysis from Bray-Curtis dissimilarity of relative OTU abundances. Separations of groups identified on the NMDS plot (mat and reference) were tested for significance using the nonparametric Analysis of Similarity (ANOSIM) test and $P$-values were corrected for multiple comparisons using Bonferroni's correction.

\section{RESULTS AND DISCUSSION}

Dives with the submersible JAGO confirmed our hypothesis that thiotrophic microbial mats are associated with the hypoxic zone of the Black Sea at the outer shelf break. We defined the hypoxic zone according to a widely accepted ecological threshold (e.g., Diaz, 2001), as the area marked by bottom water oxygen concentrations $1-63 \mu \mathrm{mol} \mathrm{L}^{-1} \mathrm{O}_{2}$. In the outer Western Crimean shelf this zone ranged from $\sim 140$ to $170 \mathrm{~m}$ water depth (with a rather uniform bottom water salinity of 20 psu, and a temperature of $8^{\circ} \mathrm{C}$ ), covering a distance of ca. $6 \mathrm{~km}$ perpendicular to the slope, as detected by the oxygen optode mounted to JAGO (Figure 1A). No larger benthic fauna was observed to graze the seafloor within this zone during 10 dives, covering about $20 \mathrm{~km}^{2}$, and the seafloor did not show signs of animal traces such as burrows.

Within this area, mats were directly associated with the chemocline, i.e., the interface between oxic and sulfidic bottom waters. This zone was positioned on average at $160 \mathrm{~m}$ water depth during our investigations in late April-early May 2010. 
However, in situ observations indicate that this zone is dynamic and fluctuates up and down, for up to $1 \mathrm{~km}$ due to internal waves and eddies (Filonov, 2000; Friedrich et al., 2014; Stanev et al., 2014; Lichtschlag et al., 2015). During the dive, the observed oxygen concentrations in bottom waters of the mat area ranged from below detection limit $\left(<1 \mu \mathrm{mol} \mathrm{L}^{-1}\right)$ at mats $1-3$ to ca. $50 \mu \mathrm{mol} \mathrm{L} \mathrm{L}^{-1}$ at mat 4 , as measured by JAGO and CTD casts. Studies of the faunal composition of the area showed a steep decrease in faunal abundances and absence of dwelling animals within this zone (Lichtschlag et al., 2015). Only very small polychaetes ( $<3 \mathrm{~mm}$ genus Victorniella) and some foraminifera (e.g., genus Vellaria) were detected around 130-170 m (Sergeeva, 2015; Sergeeva et al., 2015). Highly adapted sub-millimeter sized metazoans have been reported active previously in anoxic waters of the Bosphorus outflow area (e.g., Theristus sp.; Sergeeva et al., 2014) and other euxinic environments (e.g., Phylum Loricifera; Danovaro et al., 2010). However, these conditions are generally inhospitable to larger metazoans which dwell the seafloor and provide critical ecosystem functions such as bioturbation and sediment feeding (e.g., Levin, 2003, 2010 and references therein).

\section{Thiotrophic Mats Associate with Organic Matter Accumulations at the Chemocline}

The submersible surveys close to the position of the chemocline showed a color change of the seafloor from beige-brownish to dark-gray with increasing water depth. The seafloor was covered with a fluffy layer of greenish detritus particles, which were substantially enriched in algal pigments (Figure 2C), suggesting that this layer was composed of deposited marine snow. Cutting into the mat-covered patches with the JAGO manipulator or with push cores showed laminated, almost gelatinous layers of particle deposits of around 4-5 cm thickness that filled the seafloor depressions (Figure 1C). In contrast, the particle layer outside the mats was only around $1 \mathrm{~cm}$ thickness above a flat seafloor. The seafloor depressions ranged from few decimeters to $>3 \mathrm{~m}$ in diameter, and the darker patches of organic matter accumulations formed a slightly elevated dome within them. Using the JAGO arm for measurements in situ, and comparing to the thickness of the particle layer in the retrieved core, we estimate the depth of the depressions at around $4 \mathrm{~cm}$. They were covered partially or fully by mat-forming, whitish microbial filaments (Figure 1B). Most of the mats were $<1 \mathrm{~m}$ in diameter $(0.6 \pm 0.3 \mathrm{~m} ; n=1091)$, and rather homogeneously distributed with a few meters apart from each other (Supplementary Figure S2). The origin and distribution of the abundant depressions observed close to the chemocline at the shelf break is unknown. It may be possible that these are formed by the impact of currents by internal waves and eddies in the region (Trembanis et al., 2011; Stanev et al., 2014).

No mats were observed below the chemocline within oxygenfree sulfidic waters at $>170 \mathrm{~m}$ water depth, or above the $150 \mathrm{~m}$ isobath where the seafloor depressions were rare (Figure 1; Supplementary Figure S2). From the dimension and distribution of the mats, we estimate that they covered an area in the range of $25-55 \%$ of the explored seafloor between 150 and $170 \mathrm{~m}$ water depth. Extrapolating from our observations, the Black Sea outer shelf may host a belt of mat patches between these two isobaths, covering an area of $500-1200 \mathrm{~km}^{2}$ of Black Sea seafloor (Supplementary Figure S1).

\section{Accumulation of Organic Matter Prompts Sulfide Production for Mat Development}

Biogeochemical analyses of sediment samples from the mat-covered vs. mat-free seafloor confirmed the enhanced accumulation of organic matter underlying the mats compared to the surrounding sediments (Figures 2A-C). The pore waters from sediments with mats contained sulfide concentrations up to $450 \mu \mathrm{mol} \mathrm{L}{ }^{-1}$, and microsensor measurements showed fluxes of 0.7-3.2 mmol sulfide $\mathrm{m}^{-2}$ day $^{-1}$ (average $1.9 \mathrm{mmol}$ sulfide $\mathrm{m}^{-2}$ day $^{-1}$ ), consistent with sulfate reduction rate measurements (average $2.2 \mathrm{mmol}$ sulfide $\mathrm{m}^{-2}$ day ${ }^{-1}$ ) and porewater analyses (Figures 2E,F). Outside the mats, sulfide concentrations and fluxes were around or below detection limit, whether measured as sulfate reduction rates, with microsensors (upper $4 \mathrm{~cm}$, Figure 3 ) or in the extracted porewater (down to $10 \mathrm{~cm}$, Figure $2 \mathrm{~F}$ ). The bottom water sulfide concentrations at these depths were around detection limit (Lichtschlag et al., 2015), depending on the position of the chemocline and the hydrographical regime. Our observations indicate that the occurrence of thiotrophic mats is limited to a zone in the Black Sea with both oxygen availability and porewater sulfide fluxes high enough to reach into the surface seafloor (Figure 3). Indeed, the steep gradient of the sulfide microprofiles within the mat is consistent with the complete removal of sulfide (Lichtschlag et al., 2010).

The observed organic matter accumulations and porewater profiles in the depressions were also reflected in enhanced remineralization rates. Assuming carbon degradation was entirely fueled by sulfate reduction, total microbial remineralization below the mat was $5-10 \mathrm{mmol} \mathrm{C} \mathrm{m}^{-2}$ day $^{-1}$ based on the stoichiometry with sulfide production compared to rates of $1.3 \pm 0.5 \mathrm{mmol} \mathrm{C} \mathrm{m}{ }^{-2} \mathrm{day}^{-1}$ in the mat-free hypoxic area (Lichtschlag et al., 2015). In the anoxic zone of the shelf below the chemocline, sulfate reduction rates remain high (Weber et al., 2001; Lichtschlag et al., 2015), but the lack of oxygen represses the formation of mats.

Next we investigated the reason for the enhanced carbon and sulfur fluxes in the seafloor depressions. The organic carbon $\left(\mathrm{C}_{\text {org }}\right)$ content of the surface seafloor (top $1 \mathrm{~cm}$ ) from the mat patches and outside of the mats were highly variable and fell within the range described for the Black Sea of 1-5\% (e.g. Cowie and Hedges, 1991; Jørgensen et al., 2004). When integrating over the top $2 \mathrm{~cm}$; the patches showed significantly higher $\mathrm{C}_{\text {org }}$ compared to the surrounding reference sites averaging $4.5 \pm 1.5 \%$ vs. $3.5 \pm 1.5 \%$ outside the mat $\left[t_{(32)}=3.48\right.$, $P<0.001]$. Within the top $4 \mathrm{~cm}$ this even resulted in ca. twofold higher $\mathrm{C}_{\text {org }}$ values (Figure 2A). Also the percentage of total nitrogen integrated over the same section was elevated. However, the isotopic composition of $\mathrm{C}$ and $\mathrm{N}$ was the same inside and outside the mat (Table 1), suggesting a similar source of the deposited organic matter. Furthermore, both chloroplastic pigments from algal detritus and total hydrolyzable amino acids showed higher concentrations under the mat compared 
A

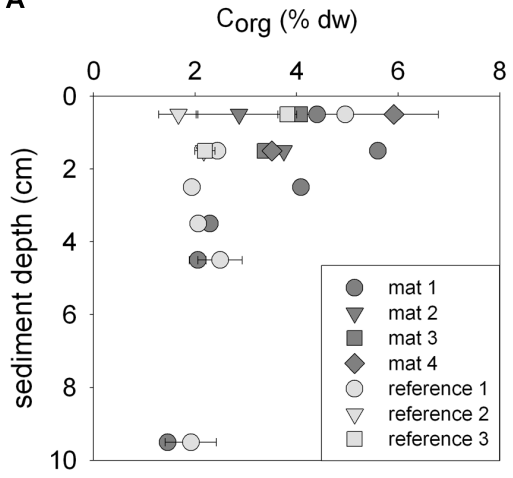

D

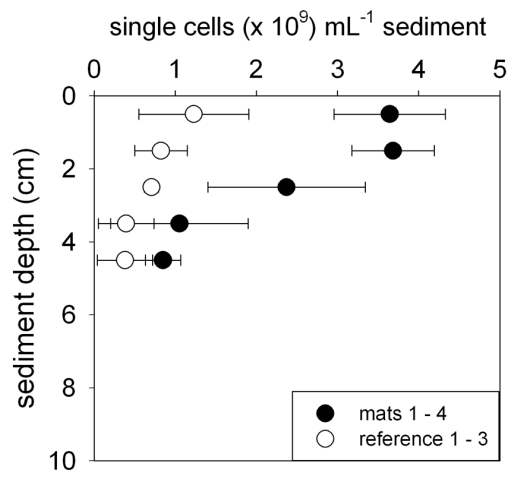

G

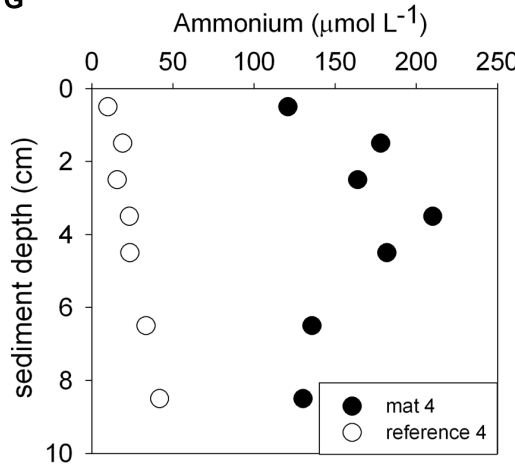

B

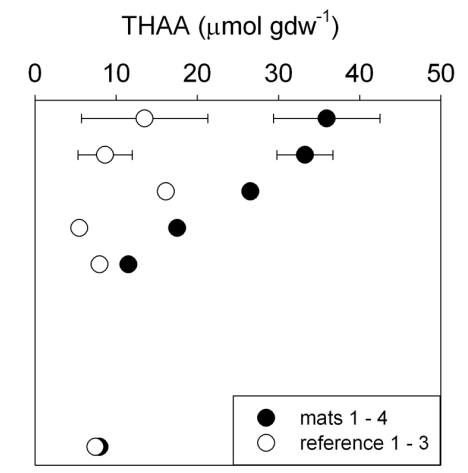

E

${ }^{35} \mathrm{~S}$-Sulfate reduction rate $\left(\mathrm{nmol} \mathrm{cm} \mathrm{d}^{-3}\right)$

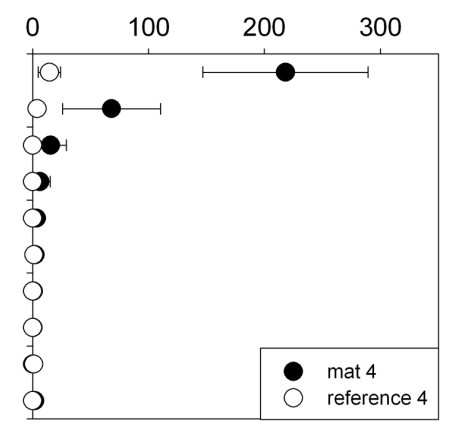

H
C $\mathrm{Chl}$ a $\left(\mu \mathrm{g} \mathrm{gdw}^{-1}\right)$

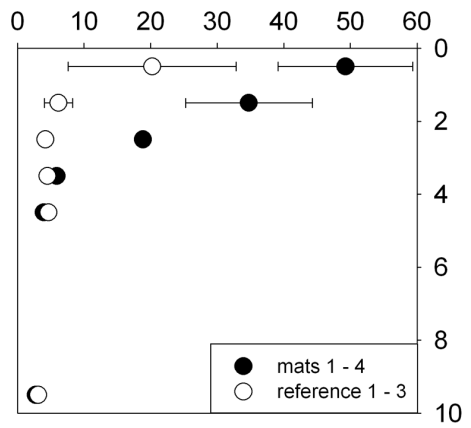

F

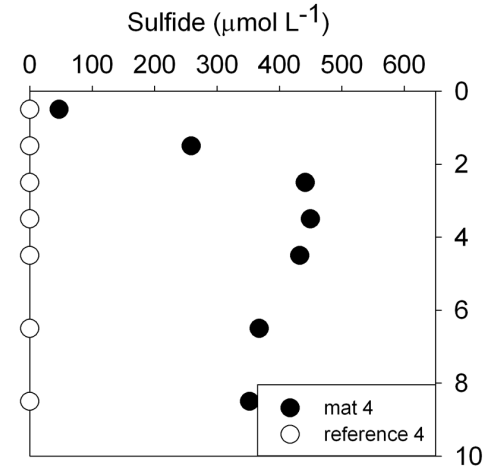

FIGURE 2 | Biogeochemical characteristics of the sediments comparing mat-covered (dark gray/black symbols) and mat-free references sites (light gray/white symbols). Content of organic carbon (A), total hydrolyzable amino acids (THAA) (B) and chlorophyll a (C), total single cells (D), radiotracer-based sulfate reduction rates $(\mathbf{E})$, concentration of sulfide $\mathbf{( F )}$, ammonium $(\mathbf{G})$ and phosphate $\mathbf{( H )}$. Symbols represent averages and error bars standard deviations when replicates were available $( \pm, n=3-5)$.

to the reference sites (Figures $\mathbf{2 B}, \mathbf{C}$ ), indicating phytodetritus accumulation in the seafloor depressions. We also tested for differences in the degradability of the bulk organic matter pool accumulating in the depressions versus on the surrounding seafloor by a number of proxies based on the above concentration measurements. This included the $\mathrm{C} / \mathrm{N}$ molar ratio (Meyers, 1994), the amino acid based degradation index (Dauwe and Middelburg, 1998; Dauwe et al., 1999) and the chlorophyll $a$ to total pigment equivalent (CPE) ratio (Pfannkuche, 1993).
The respective proxies were comparable between mat-covered sediments and the reference sites (Table 1), suggesting that local differences in the accumulation rates of matter, but not the quality and composition of the material, was responsible for the higher sulfide fluxes and subsequent development of microbial mats. Considering sediment accumulation rates of $1 \pm 0.5 \mathrm{~mm} \mathrm{year}^{-1}$ for the study area (Lichtschlag et al., 2015), apparently, the depressions in the seafloor act as detritus traps. From the shape of the sulfide, ammonium and phosphate profiles 

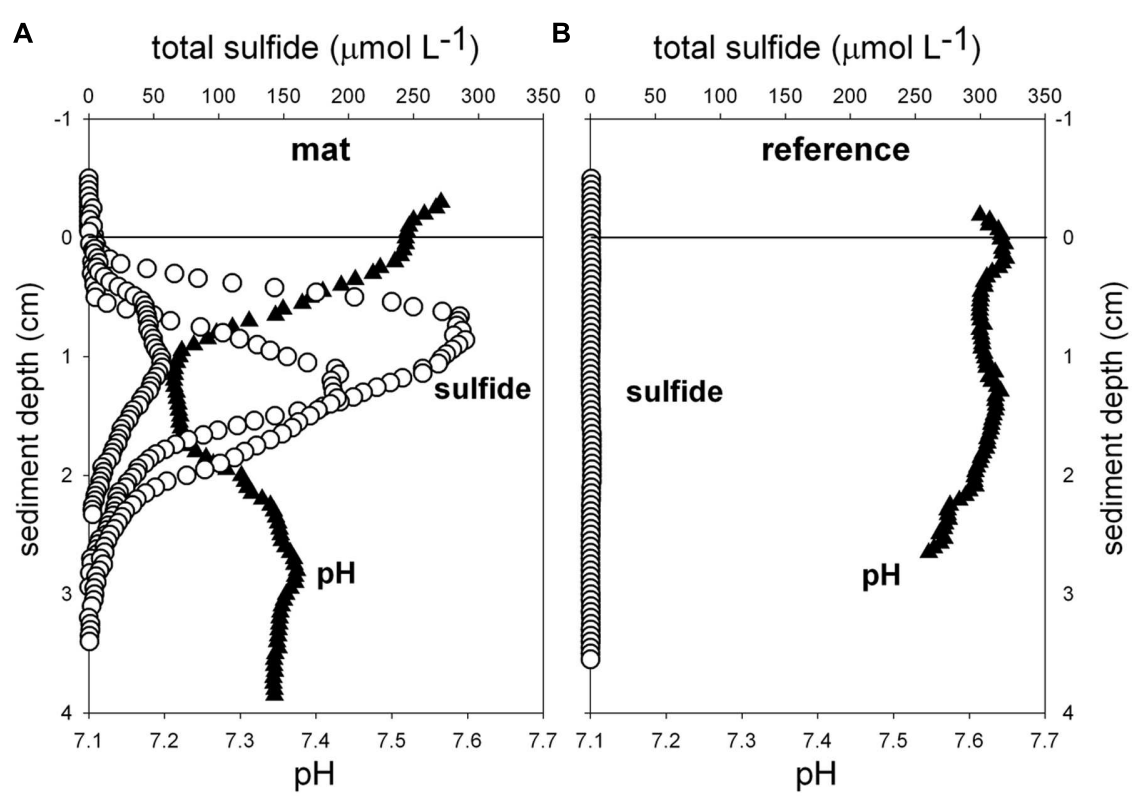

FIGURE 3 | Ex situ microprofiles of total sulfide $(n=3)$ and $\mathrm{pH}(n=1)$ measured in sediment of mat $1(\mathrm{~A})$, and in close-by sediments without mat $(\mathrm{B}$, $\boldsymbol{n}=\mathbf{1})$. Oxygen was below detection limit.

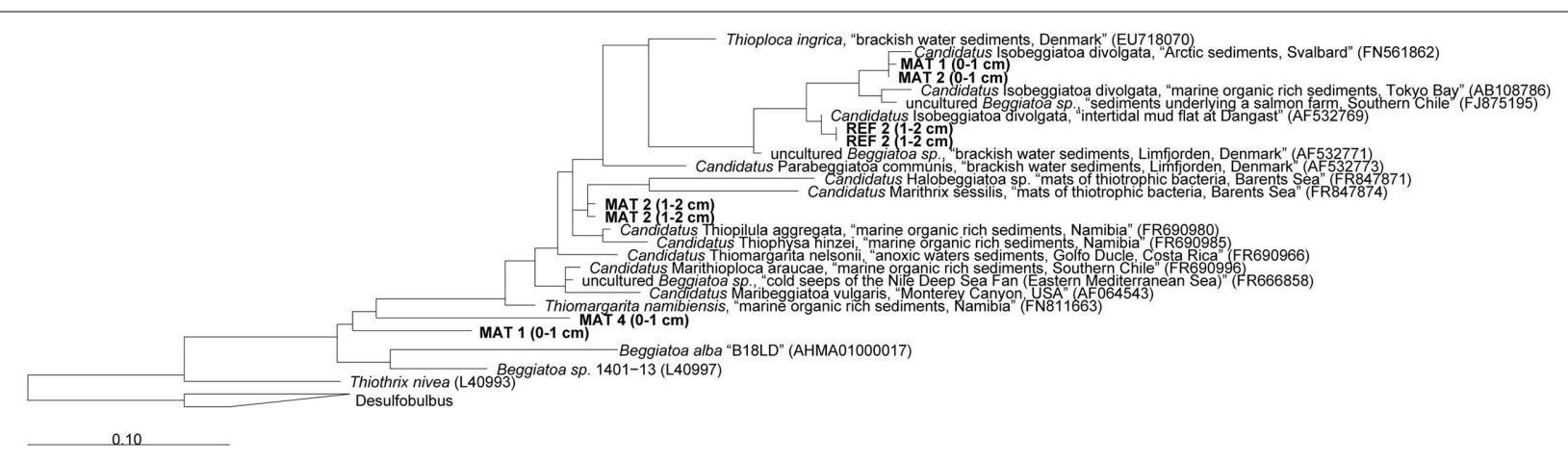

FIGURE 4 | Phylogenetic 16S rRNA gene based tree showing the affiliation of sequences extracted from mat-covered and reference sediments of the Crimea margin with other filamentous sulfur-oxidizing bacteria. Mats and references sequences were screened for relatives of large sulfur oxidizing bacteria and extracted from the data set using the "grep" function in R. Initial tree reconstruction was conducted with nearly full-length sequences (1200-1400 bp). Partial sequences were subsequently inserted into the reconstructed consensus tree by applying the parsimony criteria. The scale bar corresponds to $10 \%$ estimated sequence divergence. Phylogenetic classification was carried out with the software package ARB (Ludwig et al., 2004) based on the SILVA database (SSURef v119, release date: 24 July 2014). The phylogenetic tree was calculated with the maximum likelihood algorithm PHYML (100 bootstraps) as implemented in ARB using a positional variability filter.

these appeared as rather recent deposits not yet in steady state (Figures 2F-H).

\section{Composition and Diversity of the Thiotrophic Mats on the Crimea Margin}

The mats forming above the detritus-accumulating depressions consisted of colorless filaments ranging from 10 to $40 \mu \mathrm{m}$ diameter and up to a few mm length. The filaments contained light refracting granules of elemental sulfur (Figure 1D), explaining the whitish appearance of the mats. According to the morphology and the occasional gliding motility, many filaments resembled a Beggiatoa-like morphotype (Schulz and Jørgensen, 2001; nomenclature from Salman et al., 2011). Other filaments were seemingly non-motile under the microscope and rather represented the morphotype of "Candidatus Marithrix" (Kalanetra et al., 2004; nomenclature from Salman et al., 2011). We retrieved 16S rRNA gene sequences from the top sediment layer $(0-2 \mathrm{~cm})$ affiliated to the group of large filamentous sulfide oxidizers (Figure 4). The sequences from the mat clustered with relatives of the free-living, gliding "Candidatus Isobeggiatoa divolgata” (Mußmann et al., 2007), with the attached-living " $\mathrm{Ca}$. Marithrix sp.", and other deeply branching thiotrophs within the family Beggiatoaceae. Surprisingly, in the mat-free reference site 

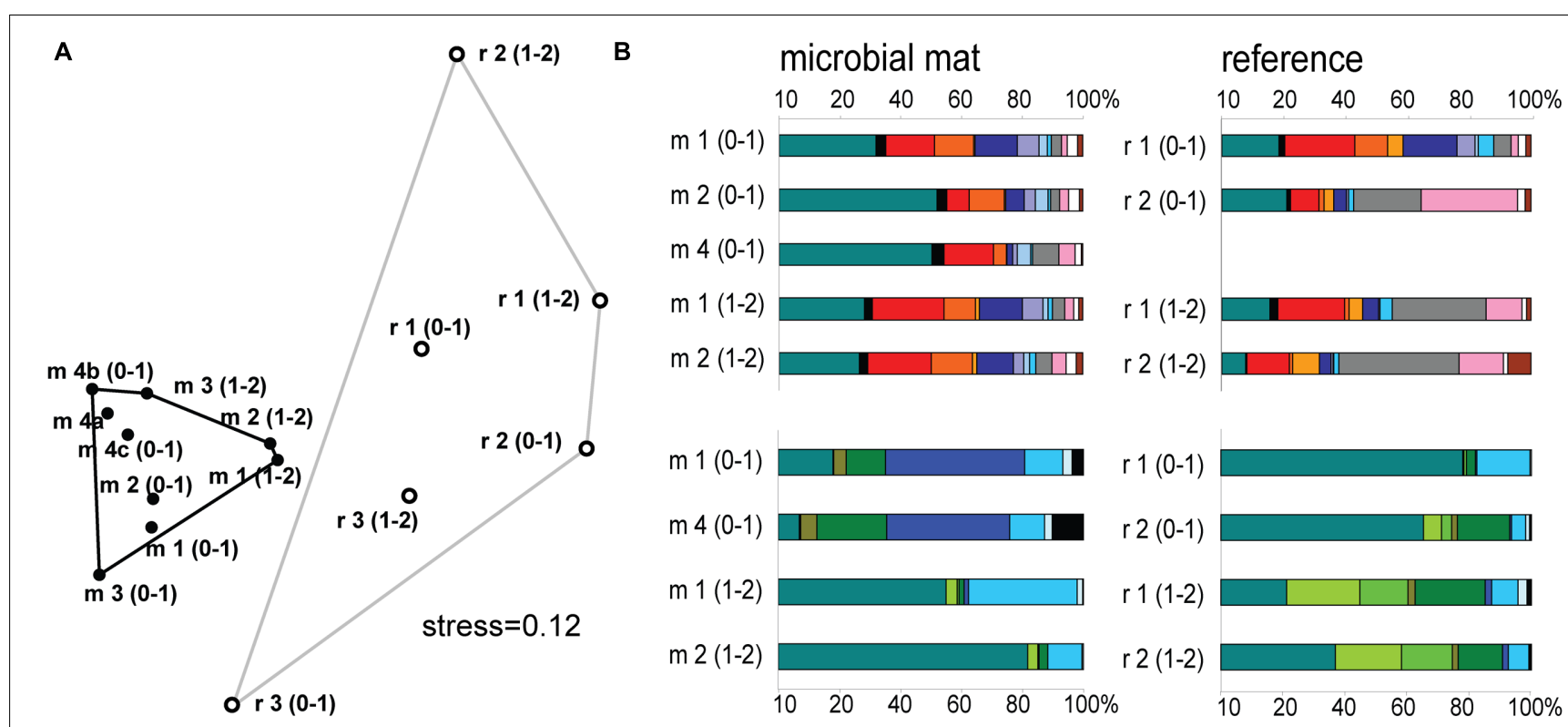

\section{Bacteria}

- Flavobacteriaceae

- Rhodobacteraceae

- Desulfobacteraceae

$\square$ Desulfobulbaceae

$\square$ Syntrophobacteraceae

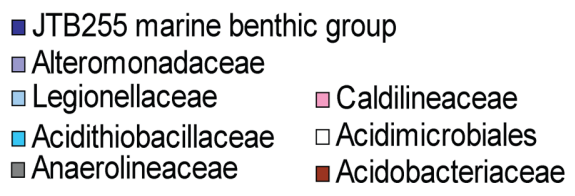

\section{Archaea}

$\square$ Marine Group I
$\square$ Marine Benthic Group B
$\square$ MCG
$\square$ Thermoprotei
- Crenarchaeota others

- Thermoplasmata $\checkmark$ Halobacteria $\square$ Methanomicrobia - Others

FIGURE 5 | (A) Nonmetric Multi Dimensional Scaling (NMDS) ordination plot based on Bray-Curtis distance matrix from ARISA profiles. Convex hulls depict significant differences between groups of mat-covered sediments (black circles) and references sites (white circles). Bonferroni corrected $P$-value < 0.001 ; Analysis of Similarity (ANOSIM) based on Bray-Curtis $R$-value $=0.7$. (B) Relative abundance of bacterial (above) and archaeal (below) sequences from the upper $2 \mathrm{~cm}(0-1$ and 1-2 cm horizons) obtained by 454-MPTS comparing mat-covered sediments (left) and references sites (right). MCG-Miscellaneous Crenarchaeotal Group.

2 (Figure 4) we also observed “ $C a$. I. divolgata” sequences, which indicates that some of the thiotrophs can be wide-spread in the Black Sea sediments as a member of the rare biosphere, and could grow into dense mats when they meet favorable conditions (Jørgensen, 2010).

We used cell counts and community fingerprinting (ARISA and 454-MPTS) to assess the distribution and composition of the bacterial and archaeal communities associated with the thiotrophic mats. Since the total DNA pool was sequenced, a fraction of extracellular DNA and dormant/dead cells can be represented in addition to the active microbial community (Torti et al., 2015 and references therein).

The mat-associated communities showed threefold higher cell abundances in the upper sediment horizons $(0-4 \mathrm{~cm}$ b.s.f.) compared to the surrounding sediments (Figure 2D). Significant differences in the bacterial community structure were evident based on the ARISA and the MPTS data comparing mat and reference sites (ARISA Bonferroni corrected $P$-value $<0.001$; Analysis of Similarity based on Bray-Curtis $R$-value $=0.7$; Figure 5A), consistent with the variations in the composition of bacterial and archaeal taxa detected by 454-MPTS (upper $2 \mathrm{~cm}$; MPTS Bonferroni corrected $P$-value $<0.05$; Analysis of Similarity based on Bray-Curtis $R$-value $=0.6$; Figure $5 \mathrm{~B}$ ).
Within the same horizon, only $45 \pm 6 \%$ of the dominant bacterial types detected by ARISA overlapped between bacterial mats and surrounding reference sediments (Figure 5A; Supplementary Table S1), and the thiotrophic mats hosted 11\% unique sequences.

The Black Sea microbiological communities associated with hydrocarbon-rich benthic ecosystems are relatively well studied. However, apart from these environments the diversity of Black Sea benthic microbial communities remains less understood. From the 454-MPTS analysis of the composition of bacterial sequences in mat-covered and surrounding sediments were retrieved 64429 reads, comprising 3766 individual OTUs by 97\% clustering (excluding singletons), in the following referred to as $\mathrm{OTU}_{0.03}$ (Supplementary Table S2).

Flavobacteriaceae dominated up to $50 \%$ of the individual $\mathrm{OTU}_{0.03}$ at the surface of the patches (Figure 5B). Flavobacteria are relevant marine polymer degraders with hydrolytic and fermentative capacities (Cottrell and Kirchman, 2000; Bernardet et al., 2002 and references therein; Lydell et al., 2004; Julies et al., 2010). Their sequence abundance was two-to fourfold higher in mat-covered sediments compared to the surrounding sediments, and generally decreased with sediment depth and with decreasing organic matter content, as observed already in the Black Sea (Romanian shelf; Tanase et al., 2009) and 
other marine habitats (Bissett et al., 2008). Probably profiting from the products of fermentation, the families of sulfate/sulfur reducers Desulfobacteraceae and Desulfobulbaceae (Muyzer and Stams, 2008) were more abundant in the mat-covered sediments compared to the surrounding sediments. These groups are typical for reduced sediments (Reese et al., 2013; Sinkko et al., 2013). Previously found associated to Beggiatoa spp. mats (Lloyd et al., 2010), appeared as the most abundant among sulfate reducing bacteria in Black Sea surface sediments at similar water depth (Ince et al., 2007). Some members of the Desulfobulbaceae are able to conduct long range electron transfer in organic rich sediments, coupling the oxidation of sulfide with oxygen over centimeter distance (Pfeffer et al., 2012). Several of the 16SrRNA gene sequences retrieved from the mat clustered with sequences identified as "cable bacteria" (Supplementary Figure S3, Pfeffer et al., 2012; Schauer et al., 2014), extending the known distribution of this group (Malkin et al., 2014). However, the lack of the characteristic $\mathrm{pH}$ signature (Figure 3) suggest they were rare, and that sulfate reduction was a main energygenerating pathway, probably from phytodetrital fermentation products (McKew et al., 2013). Two fractions of the bacterial community did not show differences between mat and matfree sediments, the families Anaerolineaceae and Caldilineaceae involved in fermentation (Yamada et al., 2006) and previously described for deep Black Sea sediments (>800 m; Schippers et al., 2012).

Also the archaeal community (39091 reads retrieved, comprising 880 individual OTUs (excluding singletons); 97\% clustering, Supplementary Table S2) showed differences between mat-covered sediments and the surrounding seafloor (Figure 5B). Thermoplasmata were typical for the mat-covered sediments, but almost absent from the surrounding sediments. They are known as facultative anaerobes performing sulfur respiration (Huber and Stetter, 2006 and references therein), suggesting a role in the consumption of sulfide (Figure 3). Crenarchaeota sequence abundances were low in the sulfidic mat-covered sediments, but were the most abundant archaeal sequence elsewhere, extending its dominance from deep Black Sea sediments (>800 m; Schippers et al., 2012) to the continental shelf. Many of the archaeal OTU $\mathrm{O}_{0.03}$ were affiliated to the Marine Group I. This clade dominated subsurface sediments at the mat-covered sediments and also the surface and subsurface of the references sites (Figure 5B). Cultivated strains affiliated to this group are described as aerobic ammonia oxidizers (Könneke et al., 2005). In agreement with our results they can inhabit oxic and anoxic environments, but little is known as to which electron acceptors they could use in the absence of oxygen (La Cono et al., 2013). In addition, we detected several types associated with the thiotrophic mats belonging to "extremophile" groups (Figure 5B), including Thermoprotei and Halobacteria considered thermophilic and halophilic correspondingly (Huber et al., 2006; Oren, 2006 and references therein). Although most of the representatives of the Halobacteria group are halophiles, uncultured members have been reported in less saline environments such as estuaries (e.g., Singh et al., 2010). Halobacteria were more abundant in the mat-covered sediments; they are known to reduce sulfur compounds in low-salt environments (Elshahed et al., 2004), however, the bottom waters presented $S=20$ during the study.

\section{CONCLUSION}

We could confirm our hypothesis of an association of thiotrophic mats with the hypoxic areas of the Black Sea margin, specifically the zone where the chemocline met the seafloor. The thiotrophic mats were formed by filamentous large sulfur bacteria related to the Beggiatoa clade. The mat habitat enriched for polymer degrading, fermenting and sulfate-reducing microorganisms including relatives of the cable bacteria. The key factor for the distribution of mat-forming thiotrophs appeared to be the proximity to the chemocline, for access to oxygen from bottom waters, and sulfide from the sediment, and for reduced grazing pressure due to the absence of fauna in hypoxic waters. We speculate that also the specific hydrographic conditions near to the shelf break are important in shaping the habitat, causing a rough seafloor topography with depressions that enhance the accumulation of relatively labile organic matter. Due to the dynamic positioning of this interface zone by water mass movement, we suggest that the thiotrophic mat zone could form a belt around the Black Sea outer shelf, covering thousand square kilometers.

\section{AUTHOR CONTRIBUTIONS}

Conception, work design, and drafting by GLJ and AB. Acquisition, analysis and data interpretation by all the authors. All the authors revised the work critically and contributed with important intellectual content, approved it for publishing and agreed for all aspects of the work in ensuring that questions related to the accuracy and integrity of any part of the work were appropriately investigated and resolved.

\section{FUNDING}

This study was financially supported by the EU $7^{\text {th }} \mathrm{FP}$ project HYPOX (in situ monitoring of oxygen depletion in hypoxic ecosystems of coastal and open seas, and land-locked water bodies) EC Grant 226213 and the Leibniz program of the DFG to $\mathrm{AB}$, as well as the Max Planck Society for additional support.

\section{ACKNOWLEDGMENTS}

We thank the officers, crew, and shipboard scientific party of R/V Maria S. Merian, Sebastian Albrecht and the JAGO team (GEOMAR, Kiel) for support at sea during the expedition MSM 15-1. We would also like to acknowledge Alban Ramette for his help on the sequencing workflow, and Frank Wenzhöfer, 
Felix Janssen, Pier Luigi Buttigieg, Stefanie Meyer, Christiane Hassenrueck, Rafael Laso-Pérez, Viola Krukenberg, and Verena Carvalho for helpful discussions. Silvio Pantoja is thanked for access to analytical facilities of the Organic Geochemistry Lab, University of Concepción COPAS Sur-Austral, and Lilian Nuñez and Paulina Concha for laboratory assistance. Daphne Donis, Wiebke and Rafael Stiens, Martina Alisch, Erika WeizBersch and Mirja Meiners are gratefully acknowledged for their assistance on board and in laboratory, and the technicians

\section{REFERENCES}

Bernardet, J., Nakagawa, Y., and Holmes, B. (2002). Proposed minimal standards for describing new taxa of the family Flavobacteriaceae and emended description of the family. Int. J. Syst. Evol. Microbiol. 52, 1049-1070. doi: 10.1099/ijs.0.02136-0

Bissett, A., Bowman, J., and Burke, C. (2008). Flavobacterial response to organic pollution. Aquat. Microb. Ecol. 51, 31-43. doi: 10.3354/ame01174

Boetius, A., and Lochte, K. (1996). Effect of organic enrichments on hydrolytic potentials and growth of bacteria in deep-sea sediments. Mar. Ecol. Prog. Ser. 140, 239-250. doi: 10.3354/meps 140239

Boetius, A., Ravenschlag, K., Schubert, C. J., Rickert, D., Widdel, F., Gieseke, A., et al. (2000). A marine microbial consortium apparently mediating anaerobic oxidation of methane. Nature 407, 623-626. doi: 10.1038/350 36572

Campbell, B. J., Engel, A. S., Porter, M. L., and Takai, K. (2006). The versatile epsilon-proteobacteria: key players in sulphidic habitats. Nat. Rev. Microbiol. 4, 458-468. doi: 10.1038/nrmicro1414

Capet, A., Becker, J. W., and Grégoire, M. (2013). Drivers, mechanisms and longterm variability of seasonal hypoxia on the Black Sea northwestern shelf is there any recovery after eutrophication? Biogeosciences 10, 3943-3962. doi: 10.5194/bg-10-3943-2013

Cardinale, M., Brusetti, L., Quatrini, P., Borin, S., Puglia, A. M., Rizzi, A., et al. (2004). Comparison of different primer sets for use in automated ribosomal intergenic spacer analysis of complex bacterial communities. Appl. Environ. Microbiol. 70, 6147-6156. doi: 10.1128/AEM.70.10.6147-6156. 2004

Cline, J. D. (1969). Spectrophotometric determination of hydrogen sulfide in natural waters. Limnol. Oceanogr. 14, 454-458. doi: 10.4319/lo.1969.14. 3.0454

Cottrell, M. T., and Kirchman, D. L. (2000). Natural assemblages of marine Proteobacteria and Members of the Cytophaga-Flavobacter cluster consuming low- and high-molecular-weight dissolved organic matter. Appl. Environ. Microbiol. 66, 1692-1697. doi: 10.1128/AEM.66.4.1692-1697.2000

Cowie, G. L., and Hedges, J. I. (1991). "Organic carbon and nitrogen geochemistry of Black Sea surface sediments from stations spanning the oxic:anoxic boundary," in Black Sea Oceanography, eds E. İzdar and J. W. Murray (Netherlands: Springer), 343-359.

Danovaro, R., Dell'Anno, A., Pusceddu, A., Gambi, C., Heiner, I., and Reinhardt Møbjerg, K. (2010). The first metazoa living in permanently anoxic conditions. BMC Biol. 8:30. doi: 10.1186/1741-7007-8-30

Dauwe, B., and Middelburg, J. J. (1998). Amino acids and hexosamines as indicators of organic matter degradation state in North Sea sediments. Limnol. Oceanogr. 43, 782-798. doi: 10.4319/lo.1998.43.5.0782

Dauwe, B., Middelburg, J. J., Herman, P. M. J., and Heip, C. H. R. (1999). Linking diagenetic alteration of amino acids and bulk organic matter reactivity. Limnol. Oceanogr. 44, 1809-1814. doi: 10.4319/lo.1999.44.7.1809

de Beer, D., Schramm, A., Santegoeds, C. M., and Kuhl, M. (1997). A nitrite microsensor for profiling environmental biofilms. Appl. Environ. Microbiol. 63, 973-977.

Diaz, R. J. (2001). Overview of hypoxia around the world. J. Environ. Qual. 30, 275-281. doi: 10.2134/jeq2001.302275x

Edgar, R. C., Haas, B. J., Clemente, J. C., Quince, C., and Knight, R. (2011). UCHIME improves sensitivity and speed of chimera detection. Bioinformatics 27, 2194-2200. doi: 10.1093/bioinformatics/btr381 of the Microsensor Group (MPI) for the construction of microsensors.

\section{SUPPLEMENTARY MATERIAL}

The Supplementary Material for this article can be found online at: http://journal.frontiersin.org/article/10.3389/fmicb. 2016.01011

Elshahed, M. S., Najar, F. Z., Roe, B. A., Oren, A., Dewers, T. A., and Krumholz, L. R. (2004). Survey of archaeal diversity reveals an abundance of halophilic archaea in a low-salt, sulfide- and sulfur-rich spring. Appl. Environ. Microbiol. 70, 2230-2239. doi: 10.1128/AEM.70.4.2230-2239.2004

Filonov, A. E. (2000). Thermic structure and intense internal waves on the narrow continental shelf of the Black Sea. J. Mar. Syst. 24, 27-40. doi: 10.1016/S09247963(99)00077-9

Fisher, M. M., and Triplett, E. W. (1999). Automated approach for ribosomal intergenic spacer analysis of microbial diversity and its application to freshwater bacterial communities. Appl. Environ. Microbiol. 65, 4630-4636.

Fossing, H. A., Gallardo, V. A., Jørgensen, B. B., Hüttel, M., Nielsen, L. P., Schulz-Vogt, H. N., et al. (1995). Concentration and transport of nitrate by the mat-forming sulphur bacterium Thioploca. Nature 374, 713-715. doi: $10.1038 / 374713 \mathrm{a} 0$

Freitag, T. E., Klenke, T., Krumbein, W. E., Gerdes, G., and Prosser, J. I. (2003). Effect of anoxia and high sulphide concentrations on heterotrophic microbial communities in reduced surface sediments (Black Spots) in sandy intertidal flats of the German Wadden Sea. FEMS Microbiol. Ecol. 44, 291-301. doi: 10.1016/S0168-6496(03)00076-X

Friedrich, J., Janssen, F., Aleynik, D., Bange, H. W., Boltacheva, N., Çagatay, M. N., et al. (2014). Investigating hypoxia in aquatic environments: diverse approaches to addressing a complex phenomenon. Biogeosciences 11, 1215-1259. doi: 10.5194/bg-11-1215-2014

Gallardo, V. A. (1977). Large benthic microbial communities in sulphide biota under Peru-Chile Subsurface Countercurrent. Nature 268, 331-332. doi: 10.1038/268331a0

Girnth, A. C., Grünke, S., Lichtschlag, A., Felden, J., Knittel, K., Wenzhöfer, F., et al. (2011). A novel, mat-forming Thiomargarita population associated with a sulfidic fluid flow from a deep-sea mud volcano. Environ. Microbiol. 13, 495-505. doi: 10.1111/j.1462-2920.2010.02353.x

Glaubitz, S., Kießlich, K., Meeske, C., Labrenz, M., and Jürgens, K. (2013). SUP05 dominates the Gammaproteobacterial sulfur oxidizer assemblages in pelagic redoxclines of the central Baltic and Black Seas. Appl. Environ. Microbiol. 79, 2767-2776. doi: 10.1128/AEM.03777-12

Grasshoff, K., Kremling, K., and Ehrhardt, M. (1983). Methods of Seawater Analysis. Berlin: Wiley-VCH.

Grünke, S., Felden, J., Liesack, W., Girnth, A.-C., de Beer, D., Wenzhöfer, F., et al. (2011). Niche differentiation among mat-forming, sulfideoxidizing bacteria at cold seeps of the Nile Deep Sea Fan (Eastern Mediterranean Sea). Geobiology 9, 330-348. doi: 10.1111/j.1472-4669.2011. 00281.x

Grünke, S., Lichtschlag, A., de Beer, D., Felden, J., Salman, V., Ramette, A., et al. (2012). Mats of psychrophilic thiotrophic bacteria associated with cold seeps of the Barents Sea. Biogeosciences 9, 2947-2960. doi: 10.5194/bg-9-29472012

Huber, H., Huber, R., and Stetter, K. O. (2006). "Thermoproteales," in The Prokaryotes, eds M. Dworkin, S. Falkow, E. Rosenberg, K.-H. Schleifer, and E. Stackebrandt (New York, NY: Springer), 10-22.

Huber, H., and Stetter, K. O. (2006). "Thermoplasmatales," in The Prokaryotes, eds M. Dworkin, S. Falkow, E. Rosenberg, K.-H. Schleifer, and E. Stackebrandt (New York, NY: Springer), 101-112.

Ince, B. K., Usenti, I., Eyigor, A., Oz, N. A., and Kolukirik, M. (2007). Analysis of methanogenic archaeal and sulphate reducing bacterial populations in deep sediments of the Black Sea. Geomicrobiol. J. 23, 285-292. doi: $10.1080 / 01490450600760724$ 
Jannasch, H. W., Nelson, D. C., and Wirsen, C. O. (1989). Massive natural occurrence of unusually large bacteria (Beggiatoa sp.) at a hydrothermal deepsea vent site. Nature 342, 834-836. doi: 10.1038/342834a0

Jeroschewski, P., Steuckart, C., and Kühl, M. (1996). An amperometric microsensor for the determination of $\mathrm{H}_{2} \mathrm{~S}$ in aquatic environments. Anal. Chem. 68, 43514357. doi: 10.1021/ac960091b

Jørgensen, B. B. (1977). Distribution of colorless sulfur bacteria (Beggiatoa spp.) in a coastal marine sediment. Mar. Biol. 41, 19-28. doi: 10.1007/BF00390577

Jørgensen, B. B. (1978). A comparison of methods for the quantification of bacterial sulfate reduction in coastal marine sediments: 1 . Measurements with radiotracer techniques. Geomicrobiol. J. 1, 11-27. doi: 10.1080/01490457809377721

Jørgensen, B. B. (2010). Big sulfur bacteria. ISME J. 4, 1083-1084. doi: 10.1038/ismej.2010.106

Jørgensen, B. B., Böttcher, M. E., Lüschen, H., Neretin, L. N., and Volkov, I. I. (2004). Anaerobic methane oxidation and a deep H2S sink generate isotopically heavy sulfides in Black Sea sediments. Geochim. Cosmochim. Acta 68, 20952118. doi: 10.1016/j.gca.2003.07.017

Jørgensen, B. B., Fossing, H., Wirsen, C. O., and Jannasch, H. W. (1991). Sulfide oxidation in the anoxic Black Sea chemocline. Deep Sea Res. A 38, S1083-S1103. doi: $10.1111 /$ gbi.12089

Jørgensen, B. B., Weber, A., and Zop, J. (2001). Sulfate reduction and anaerobic methane oxidation in Black Sea sediments. Deep Sea Res. Part I Oceanogr. Res. Pap. 48, 2097-2120. doi: 10.1016/S0967-0637(01)00007-3

Joye, S. B., Boetius, A., Orcutt, B. N., Montoya, J. P., Schulz, H. N., Erickson, M. J., et al. (2004). The anaerobic oxidation of methane and sulfate reduction in sediments from Gulf of Mexico cold seeps. Chem. Geol. 205, 219-238. doi: 10.1016/j.chemgeo.2003.12.019

Julies, E. M., Fuchs, B. M., Arnosti, C., and Brüchert, V. (2010). Organic carbon degradation in anoxic organic-rich shelf sediments: biogeochemical rates and microbial abundance. Geomicrobiol. J. 27, 303-314. doi: 10.1080/01490450903410464

Kalanetra, K. M., Huston, S. L., and Nelson, D. C. (2004). Novel, attached, sulfuroxidizing bacteria at shallow hydrothermal vents possess vacuoles not involved in respiratory nitrate accumulation. Appl. Environ. Microbiol. 70, 7487-7496. doi: 10.1128/AEM.70.12.7487-7496.2004

Kallmeyer, J., Ferdelman, T. G., Weber, A., Fossing, H., and Jørgensen, B. B. (2004). A cold chromium distillation procedure for radiolabeled sulfide applied to sulfate reduction measurements. Limnol. Oceanogr. Methods 2, 171-180. doi: 10.4319/lom.2004.2.171

Kamp, A., Stief, P., and Schulz-Vogt, H. N. (2006). Anaerobic sulfide oxidation with nitrate by a freshwater Beggiatoa enrichment culture. Appl. Environ. Microbiol. 72, 4755-4760. doi: 10.1128/AEM.00163-06

Karl, D. M. (1978). Distribution, abundance, and metabolic states of microorganisms in the water column and sediments of the Black Sea. Limnol. Oceanogr. 23, 936-949. doi: 10.4319/lo.1978.23.5.0936

Klindworth, A., Pruesse, E., Schweer, T., Peplies, J., Quast, C., Horn, M., et al. (2013). Evaluation of general 16S ribosomal RNA gene PCR primers for classical and next-generation sequencing-based diversity studies. Nucleic Acids Res. 41:e1. doi: 10.1093/nar/gks808

Könneke, M., Bernhard, A. E., de la Torre, J. R., Walker, C. B., Waterbury, J. B., and Stahl, D. A. (2005). Isolation of an autotrophic ammonia-oxidizing marine archaeon. Nature 437, 543-546. doi: 10.1038/nature03911

La Cono, V., La Spada, G., Arcadi, E., Placenti, F., Smedile, F., Ruggeri, G., et al. (2013). Partaking of Archaea to biogeochemical cycling in oxygen-deficient zones of meromictic saline Lake Faro (Messina, Italy). Environ. Microbiol. 15, 1717-1733. doi: 10.1111/1462-2920.12060

Lehto, N., Glud, R. N., á Norð̈i, G., Zhang, H., and Davison, W. (2014). Anoxic microniches in marine sediments induced by aggregate settlement: biogeochemical dynamics and implications. Biogeochemistry 119, 307-327.

Levin, L. A. (2003). Oxygen minimum zone benthos: adaptation and community response to hypoxia. Oceanogr. Mar. Biol. 41, 1-45.

Levin, L. A. (2010). Anaerobic metazoans: no longer an oxymoron. BMC Biol. 8:31. doi: 10.1186/1741-7007-8-31

Lichtschlag, A., Donis, D., Janssen, F., Jessen, G. L., Holtappels, M., Wenzhöfer, F., et al. (2015). Effects of fluctuating hypoxia on benthic oxygen consumption in the Black Sea (Crimean shelf). Biogeosciences 12, 5075-5092. doi: 10.5194/bg12-5075-2015
Lichtschlag, A., Felden, J., and Bru, V. (2010). Geochemical processes and chemosynthetic primary production in different thiotrophic mats of the Håkon Mosby Mud Volcano (Barents Sea). Limnol. Oceanogr. 55, 931-949. doi: 10.4319/lo.2009.55.2.0931

Lindroth, P., and Mopper, K. (1979). High performance liquid chromatographic determination of subpicomole amounts of amino acids by precolumn fluorescence derivatization with o-phthaldialdehyde. Anal. Chem. 51, 16671674. doi: 10.1021/ac50047a019

Lloyd, K. G., Albert, D. B., Biddle, J. F., Chanton, J. P., Pizarro, O., and Teske, A. (2010). Spatial structure and activity of sedimentary microbial communities underlying a Beggiatoa spp. mat in a Gulf of Mexico hydrocarbon seep. PLoS ONE 5:e8738. doi: 10.1371/journal.pone.0008738

Ludwig, W., Strunk, O., Westram, R., Richter, L., Meier, H., Yadhukumar, et al. (2004). ARB: a software environment for sequence data. Nucleic Acids Res. 32, 1363-1371. doi: 10.1093/nar/gkh293

Lydell, C., Dowell, L., Sikaroodi, M., Gillevet, P., and Emerson, D. (2004). A population survey of members of the phylum Bacteroidetes isolated from salt marsh sediments along the east coast of the United States. Microb. Ecol. 48, 263-273. doi: 10.1007/s00248-003-1068-x

Macalady, J. L., Dattagupta, S., Schaperdoth, I., Jones, D. S., Druschel, G. K., and Eastman, D. (2008). Niche differentiation among sulfur-oxidizing bacterial populations in cave waters. ISME J. 2, 590-601. doi: 10.1038/ismej.2008.25

Macalady, J. L., Lyon, E. H., Koffman, B., Albertson, L. K., Meyer, K., Galdenzi, S., et al. (2006). Dominant microbial populations in limestone-corroding stream biofilms, Frasassi cave system, Italy. Appl. Environ. Microbiol. 72, 5596-5609. doi: 10.1128/AEM.00715-06

Malkin, S. Y., Rao, A. M., Seitaj, D., Vasquez-Cardenas, D., Zetsche, E.-M., HidalgoMartinez, S., et al. (2014). Natural occurrence of microbial sulphur oxidation by long-range electron transport in the seafloor. ISME J. 8, 1843-1854. doi: 10.1038/ismej.2014.41

Margulies, M., Egholm, M., Altman, W. E., Attiya, S., Bader, J. S., Bemben, L. A., et al. (2005). Genome sequencing in microfabricated high-density picolitre reactors. Nature 437, 376-380.

McKew, B. A., Dumbrell, A. J., Taylor, J. D., McGenity, T. J., and Underwood, G. J. C. (2013). Differences between aerobic and anaerobic degradation of microphytobenthic biofilm-derived organic matter within intertidal sediments. FEMS Microbiol. Ecol. 84, 495-509. doi: 10.1111/1574-6941.12077

Meyer, S., Wegener, G., Lloyd, K. G., Teske, A., Boetius, A., and Ramette, A. (2013). Microbial habitat connectivity across spatial scales and hydrothermal temperature gradients at Guaymas Basin. Front. Microbiol. 4:207. doi: 10.3389/fmicb.2013.00207

Meyers, P. A. (1994). Preservation of elemental and isotopic source identification of sedimentary organic matter. Chem. Geol. 114, 289-302. doi: 10.1016/00092541(94)90059-0

Møller, M. M., Nielsen, L. P., and Jørgensen, B. B. (1985). Oxygen responses and mat formation by Beggiatoa spp. Appl. Environ. Microbiol. 50, 373-382.

Murray, J. W., Stewart, K., Kassakian, S., Krynytzky, M., and DiJulio, D. (2007). "Oxic, suboxic and anoxic conditions in the Black Sea," in The Black Sea Flood Question: Changes in Coastline, Climate, and Human Settlement, eds V. Yanko-Hombach, A. S. Gilbert, N. Panin, and P. M. Dolukhanov (Amsterdam: Springer), 1-21.

Muyzer, G., and Stams, A. J. M. (2008). The ecology and biotechnology of sulphatereducing bacteria. Nat. Rev. Microbiol. 6, 441-454. doi: 10.1038/nrmicro1892

Mußmann, M., Hu, F. Z., Richter, M., de Beer, D., Preisler, A., Jørgensen, B. B., et al. (2007). Insights into the genome of large sulfur bacteria revealed by analysis of single filaments. PLoS Biol. 5:e230. doi: 10.1371/journal.pbio.0050230

Mußmann, M., Schulz, H. N., Strotmann, B., Kjaer, T., Nielsen, L. P., RossellóMora, R. A., et al. (2003). Phylogeny and distribution of nitrate-storing Beggiatoa spp. in coastal marine sediments. Environ. Microbiol. 5, 523-533. doi: 10.1046/j.1462-2920.2003.00440.x

Neira, C., and Rackemann, M. (1996). Black spots produced by buried macroalgae in intertidal sandy sediments of the Wadden Sea: effects on the meiobenthos. J. Sea Res. 36, 153-170. doi: 10.1016/S0077-7579(96)90046-0

Oksanen, J., Blanchet, G., Kindt, R., Legendre, P., and O'Hara, B. (2010). vegan: Community Ecology Package. Available at: https://github.com/vegandevs/vegan

Oren, A. (2006). “The order halobacteriales," in The Prokaryotes, eds M. Dworkin, S. Falkow, E. Rosenberg, K.-H. Schleifer, and E. Stackebrandt (New York, NY: Springer), 113-164 
Panin, N., and Jipa, D. (2002). Danube river sediment input and its interaction with the north-western Black Sea. Estuar. Coast. Shelf Sci. 54, 551-562. doi: 10.1006/ecss.2000.0664

Pante, E., and Simon-Bouhet, B. (2013). marmap: a package for importing, plotting and analyzing bathymetric and topographic data in R. PLoS ONE 8:e73051. doi: 10.1371/journal.pone.0073051

Pantoja, S., and Lee, C. (1999). Peptide decomposition by extracellular hydrolysis in coastal seawater and salt marsh sediment. Mar. Chem. 63, 273-291. doi: 10.1016/S0304-4203(98)00067-X

Pantoja, S., and Lee, C. (2003). Amino acid remineralization and organic matter lability in Chilean coastal sediments. Org. Geochem. 34, 1047-1056. doi: 10.1016/S0146-6380(03)00085-8

Pfannkuche, O. (1993). Benthic response to the sedimentation of particulate organic matter at the BIOTRANS station, $47^{\circ} \mathrm{N}, 20^{\circ} \mathrm{W}$. Deep Sea Res. Part II Top. Stud. Oceanogr. 40, 135-149. doi: 10.1016/0967-0645(93)90010-K

Pfeffer, C., Larsen, S., Song, J., Dong, M., Besenbacher, F., Meyer, R. L., et al. (2012). Filamentous bacteria transport electrons over centimetre distances. Nature 491, 218-221. doi: 10.1038/nature11586

Preisler, A., de Beer, D., Lichtschlag, A., Lavik, G., Boetius, A., and Jørgensen, B. B. (2007). Biological and chemical sulfide oxidation in a Beggiatoa inhabited marine sediment. ISME J. 1, 341-353.

Pruesse, E., Quast, C., Knittel, K., Fuchs, B. M., Ludwig, W., Peplies, J., et al. (2007). SILVA: a comprehensive online resource for quality checked and aligned ribosomal RNA sequence data compatible with ARB. Nucleic Acids Res. 35, 7188-7196. doi: 10.1093/nar/gkm864

Quince, C., Lanzén, A., Curtis, T. P., Davenport, R. J., Hall, N., Head, I. M., et al. (2009). Accurate determination of microbial diversity from 454 pyrosequencing data. Nat. Methods 6, 639-641. doi: 10.1038/nmeth. 1361

Ramette, A. (2007). Multivariate analyses in microbial ecology. FEMS Microbiol. Ecol. 62, 142-160. doi: 10.1111/j.1574-6941.2007.00375.x

Reese, B. K., Mills, H. J., Dowd, S. E., and Morse, J. W. (2013). Linking molecular microbial ecology to geochemistry in a coastal hypoxic zone. Geomicrobiol. J. 30, 160-172. doi: 10.1080/01490451.2012. 659331

Ross, D. A., Degens, E. T., and MacIlvaine, J. (1970). Black Sea: recent sedimentary history. Science 170, 163-165. doi: 10.1126/science.170.3954.163

Salman, V., Amann, R., Girnth, A.-C., Polerecky, L., Bailey, J. V., Høgslund, S., et al. (2011). A single-cell sequencing approach to the classification of large, vacuolated sulfur bacteria. Syst. Appl. Microbiol. 34, 243-259. doi: 10.1016/j.syapm.2011.02.001

Schauer, R., Risgaard-petersen, N., Kjeldsen, K. U., Bjerg, J. J. T., Jørgensen, B. B., Schramm, A., et al. (2014). Succession of cable bacteria and electric currents in marine sediment. ISME J. 8, 1314-1322. doi: 10.1038/ismej.2013.239

Schippers, A., Kock, D., Höft, C., Köweker, G., and Siegert, M. (2012). Quantification of microbial communities in subsurface marine sediments of the Black Sea and off Namibia. Front. Microbiol. 3:16. doi: 10.3389/fmicb.2012.00016

Schloss, P. D., Gevers, D., and Westcott, S. L. (2011). Reducing the effects of PCR amplification and sequencing artifacts on $16 \mathrm{~S}$ rRNA-based studies. PLoS ONE 6:e27310. doi: 10.1371/journal.pone.0027310

Schloss, P. D., Westcott, S. L., Ryabin, T., Hall, J. R., Hartmann, M., Hollister, E. B., et al. (2009). Introducing mothur: open-source, platformindependent, community-supported software for describing and comparing microbial communities. Appl. Environ. Microbiol. 75, 7537-7541. doi: 10.1128/AEM.01541-09

Schubert, C. J., Niggemann, J., Klockgether, G., and Ferdelman, T. G. (2005). Chlorin index: a new parameter for organic matter freshness in sediments. Geochem. Geophys. Geosyst. 6:Q03005. doi: 10.1029/2004GC000837

Schulz, H. N. (2006). "The genus Thiomargarita", in The prokaryotes, eds M. Dworkin, S. Falkow, E. Rosenberg, K.-H. Schleifer, and E. Stackebrandt (New York, NY: Springer), 1156-1163.

Schulz, H. N., Brinkhoff, T., Ferdelman, T. G., Mariné, M. H., Teske, A., and Jørgensen, B. B. (1999). Dense populations of a giant sulfur bacterium in Namibian shelf sediments. Science 284, 493-495. doi: 10.1126/science.284.5413.493

Schulz, H. N., and Jørgensen, B. B. (2001). Big bacteria. Annu. Rev. Microbiol. 55, 105-137. doi: 10.1146/annurev.micro.55.1.105
Seeberg-Elverfeldt, J., Schlüter, M., Feseker, T., and Kölling, M. (2005). Rhizon sampling of porewaters near the sediment-water interface of aquatic systems. Limnol. Oceanogr. Methods 3, 361-371. doi: 10.4319/lom.2005. 3.361

Sergeeva, N. G. (2015). "The modern faunal anoxic zone of the Black Sea as a remanent of the ancient anoxic biosphere," in Proceedings of the Third Plenary and Field trip from the Caspian to the Mediterranean, Asthrakan, 144-148.

Sergeeva, N. G., Mazlumyan, S. A., Lichtschlag, A., and Holtappels, M. (2014). Benthic protozoa and metazoa living under anoxic and sulfide conditions in the Black Sea: direct observations of actively moving ciliophora and nematoda. Int. J. Mar. Sci. 4, 1-11.

Sergeeva, N. G., Zaika, V. E., and Anikeeva, O. V. (2015). An overview on distribution and abundance of meiobenthic foraminifera in the Black Sea. Ecol. Montenegrina 2, 117-134.

Singh, S. K., Verma, P., Ramaiah, N., Chandrashekar, A. A., and Shouche, Y. S. (2010). Phylogenetic diversity of archaeal 16S rRNA and ammonia monooxygenase genes from tropical estuarine sediments on the central west coast of India. Res. Microbiol. 161, 177-186. doi: 10.1016/j.resmic.2010. 01.008

Sinkko, H., Lukkari, K., Sihvonen, L. M., Sivonen, K., Leivuori, M., Rantanen, M., et al. (2013). Bacteria contribute to sediment nutrient release and reflect progressed eutrophication-driven hypoxia in an organicrich continental sea. PLoS ONE 8:e67061. doi: 10.1371/journal.pone.00 67061

Sorokin, Y. I. (1972). The bacterial population and the processes of hydrogen sulphide oxidation in the Black Sea. ICES J. Mar. Sci. 34, 423-454. doi: 10.1093/icesjms/34.3.423

Stanev, E. V., He, Y., Staneva, J., and Yakushev, E. (2014). Mixing in the Black Sea detected from the temporal and spatial variability of oxygen and sulfide - Argo float observations and numerical modelling. Biogeosciences 11, 5707-5732. doi: 10.5194/bg-11-5707-2014

Tanase, A., Vassu, T., and Trasca, C. (2009). In situ visualization of natural microbial communities in Black Sea coastal shelf sediments. Rom. Biotechnol. Lett. 14, 4187-4193.

Teske, A., and Nelson, D. C. (2006). "The genera Beggiatoa and Thioploca”, in The Prokaryotes, eds M. Dworkin, S. Falkow, E. Rosenberg, K.-H. Schleifer, and E. Stackebrandt (New York, NY: Springer), 784-810. doi: 10.1007/0-387-30746-X

Thamdrup, B., and Canfield, D. E. (1996). Pathways of carbon oxidation in continental margin sediments off central Chile. Limnol. Oceanogr. 41, 16291650. doi: 10.4319/lo.1996.41.8.1629

Torti, A., Lever, M. A., and Jørgensen, B. B. (2015). Origin, dynamics, and implications of extracellular DNA pools in marine sediments. Mar. Genom. 24, 185-196. doi: 10.1016/j.margen.2015.08.007

Trembanis, A. C., Nebel, S., Skarke, A., Coleman, D. F., Ballard, R. D., Yankovsky, A., et al. (2011). "Bedforms, coastal-trapped waves, and scour process observations from the continental shelf of the northern Black Sea," in Geology and Geoarchaelogy of the Black Sea Region: Beyond the Flood Hypothesis: Geological Society of America Special Paper Vol. 473, eds I. V. Buynevich, V. Yanko-Hombach, A. S. Gilbert, and R. Martin (Boulder, CO: Geological Society of America), 165-178.

Urich, T., Lanzén, A., Stokke, R., Pedersen, R. B., Bayer, C., Thorseth, I. H., et al. (2014). Microbial community structure and functioning in marine sediments associated with diffuse hydrothermal venting assessed by integrated meta-omics. Environ. Microbiol. 16, 2699-2710. doi: 10.1111/1462-2920. 12283

Velji, M. I., and Albright, L. J. (1986). Microscopic enumeration of attached marine bacteria of seawater, marine sediment, fecal matter, and kelp blade samples following pyrophosphate and ultrasound treatments. Can. J. Microbiol. 32, 121-126. doi: 10.1139/m86-024

Vetriani, C., Tran, H. V., and Kerkhof, L. J. (2003). Fingerprinting microbial assemblages from the oxic/anoxic chemocline of the Black Sea. Appl. Environ. Microbiol. 69, 6481-6488. doi: 10.1128/AEM.69.11.6481-6488.2003

Weber, A., Riess, W., Wenzho, F., and Jørgensen, B. B. (2001). Sulfate reduction in Black Sea sediments: in situ and laboratory radiotracer measurements from the shelf to 2000 m depth. Deep Sea Res. Part I Oceanogr. Res. Pap. 48, 2073-2096. doi: 10.1016/S0967-0637(01)00006-1

Williams, L. A., and Reimers, C. E. (1983). Role of bacterial mats in oxygen-deficient marine basins and coastal upwelling regimes: preliminary 
report. Geology 11:267. doi: 10.1130/0091-7613 (1983) 11<267:ROBMIO>2. $0 . \mathrm{CO} ; 2$

Winkler, L. W. (1888). Die Bestimmung des im Wasser gelösten Sauerstoffes. Berichte der Dtsch. Chem. Gesellschaft 21, 2843-2854. doi: 10.1002/cber.188802102122

Wirsen, C. O., Sievert, S. M., Cavanaugh, C. M., Molyneaux, S. J., Ahmad, A., Taylor, L. T., et al. (2002). Characterization of an autotrophic sulfideoxidizing marine Arcobacter sp. That Produces Filamentous Sulfur. Appl. Environ. Microbiol. 68, 316-325. doi: 10.1128/AEM.68.1.316-325. 2002

Yamada, T., Sekiguchi, Y., Hanada, S., Imachi, H., Ohashi, A., Harada, H., et al. (2006). Anaerolinea thermolimosa sp. nov., Levilinea saccharolytica gen. nov., sp. nov. and Leptolinea tardivitalis gen. nov., sp. nov., novel filamentous anaerobes, and description of the new classes Anaerolineae classis nov. and
Caldilineae classis nov. Int. J. Syst. Evol. Microbiol. 56, 1331-1340. doi: 10.1099/ijs.0.64169-0

Conflict of Interest Statement: The authors declare that the research was conducted in the absence of any commercial or financial relationships that could be construed as a potential conflict of interest.

Copyright (c) 2016 Jessen, Lichtschlag, Struck and Boetius. This is an open-access article distributed under the terms of the Creative Commons Attribution License (CC BY). The use, distribution or reproduction in other forums is permitted, provided the original author(s) or licensor are credited and that the original publication in this journal is cited, in accordance with accepted academic practice. No use, distribution or reproduction is permitted which does not comply with these terms. 